\title{
Pengaruh Kualitas Pelayanan Publik Terhadap Kepuasan Masyarakat di Dinas Tenaga Kerja dan Transmigrasi Kabupaten Bantul Daerah Istimewa Yogyakarta
}

\author{
Wilis Fahlefi \\ Akademi Manajemen Administrasi Yogyakarta \\ email : wilis.fahlefi@gmail.com
}

\begin{abstract}
Abstrak
Tujuan penelitian ini adalah untuk mengetahui pengaruh kualitas pelayanan publik terhadap kepuasan masyarakat pada bidang pelayanan penempatan tenaga kerja di dinas tenaga kerja dan transmigrasi kabupaten bantul Daerah Istimewa Yogyakarta. Pengambilan sampel dalam populasi ini menggunakan teknik non-probability sampling dengan jenis accidental sampling . Populasi masyarakat yang berkunjung ke dinas tenaga kerja dan transmigrasi kabupaten bantul D.I.Yogyakarta sebanyak 50. Sampel yang diambil berjumlah 44. Pengumpulan data dilakukan dengan menyebarkan kuesioner kepada responden. Teknik pengumpulan dengan menggunakan SPSS.17. berdasarkan hasil penelitian dinyatakan bahwa variabel Kualitas Pelayanan Publik berpengaruh positif dan signifikan terhadap kepuasan masyarakat, mempunyai nilai signifikan sebesar $0.000<0,05$.
\end{abstract}

\section{Kata Kunci : Kualitas Pelayanan dan Kepuasan}

\begin{abstract}
The purpose of this study was to determine the effect of the quality of public services on community satisfaction in the field of labor placement services at the Manpower and Transmigration Office of Bantul Regency, Special Region of Yogyakarta. Sampling in this population uses a non-probability sampling technique with the type of accidental sampling. The population of people who visited the Manpower and Transmigration Office of Bantul Regency, D.I.Yogyakarta, was 50. The sample taken was 44. Data was collected by distributing questionnaires to respondents. The collection technique using SPSS.17. Based on the results of the study, it was stated that the Public Service Quality variable had a positive and significant effect on community satisfaction, having a significant value of $0.000<0.05$.
\end{abstract}

Keywords: Service Quality and Satisfaction

\section{PENDAHULUAN}

Pelayanan publik selama ini menjadi bagian penting di mana negara diwakili pemerintah berinteraksi dengan masyarakat. Keberhasilan dalam pelayanan publik akan mendorong tingginya dukungan masyarakat terhadap kinerja pemerintah. Pelayanan publik adalah perihal kemudahan yang diberikan kepada masyarakat sehubungan dengan barang dan jasa. Berdasarkan Undang-Undang Nomor 25 Tahun 2009 Tentang Pelayanan Publik pasal satu 1 ayat 1 yang dimaksud dengan Pelayanan Publik adalah kegiatan atau rangkaian kegiatan dalam rangka pemenuhan kebutuhan pelayanan sesuai dengan peraturan perundang-undangan bagi setiap warga negara dan penduduk atas barang, jasa, dan/atau pelayanan administratif yang disediakan oleh penyelenggara pelayanan publik.

Kantor Dinas Tenaga Kerja dan Transmigrasi Kabupaten Bantul merupakan salah satu kantor pemerintahan yang aktivitasnya memberikan pelayanan publik kepada masyarakat. 
Bentuk layanan yang diberikan berhubungan dengan bidang Ketenagakerjaan dan Ketransmigrasian. Seperti, Bidang Pelatihan Kerja dan Produktivitas Kerja mempunyai tugas melaksanakan perumusan dan pelaksanaan kebijakan bidang pelatihan kerja dan produktivitas, contoh: pemberian bimbingan teknis dan supervise bidang kelembagaan pelatihan, produktivitas dan standarisasi serta pelatihan dan pemagangan; Bidang Penempatan Tenaga Kerja, Perluasan Kerja dan Transmigrasi mempunyai tugas melaksanakan perumusan dan pelaksanaan kebijakan bidang penempatan tenaga kerja, perluasan kerja dan transmigrasi, contoh: pelaksanaan monitoring, evaluasi, dan pelaporan bidang penempatan tenaga kerja, perluasan kerja dan transmigrasi; Bidang Hubungan Industrial dan Kesejahteraan Pekerja mempunyai tugas melaksanakan perumusan dan pelaksanaan kebijakan bidang hubungan industrial dan kesejahteraan pekerja, contoh: pelaksanaan monitoring evaluasi dan pelaporan bidang persyaratan kerja, kesejahteraan pekerja dan jaminan sosial tenaga kerja, serta penyelesaian perselisihan hubungan industrial.

Menurut Nasution (Suandi, 2019:16), kepuasan pelanggan (masyarakat) adalah suatu keadaan di mana kebutuhan, keinginan, dan harapan pelanggan dapat terpenuhi melalui produk yang dikonsumsi. Pasolong (Suandi, 2019:16-17) menyatakan bahwa semakin baik kepemerintahan dan kualitas pelayanan yang diberikan, maka akan semakin tinggi kepercayaan masyarakat (high trust). Kepercayaan masyarakat akan semakin tinggi apabila masyarakat mendapatkan pelayanan yang baik dan merasa terpuaskan akan pelayanan tersebut.

Pada Kantor Dinas Tenaga Kerja dan Transmigrasi Kabupaten Bantul terkhusus di bidang Pelayanan Penempatan Tenaga Kerja, sebagian besar masyarakat belum memahami syarat-syarat dan prosedur pendaftaran yang dilakukan secara online. Sedangkan pada saat pengisian data secara online sering terjadi gangguan pada server atau system error. Apabila system error terjadi maka pendaftar harus melakukan pengisian data ulang. Sehingga hal ini dapat mengurangi tingkat kepuasan masyarakat terhadap pelayanan publik di Dinas Tenaga Kerja dan Transmigrasi Kabupaten Bantul.

Berdasarkan dari uraian di atas, maka penulis tertarik untuk mengkaji lebih dalam dan tertarik untuk melakukan penulisan, dalam bentuk Laporan Tugas Akhir dengan judul "Pengaruh Kualitas Pelayanan Publik Terhadap Kepuasan Masyarakat di Dinas Tenaga Kerja dan Transmigrasi Kabupaten Bantul Daerah Istimewa Yogyakarta".

\section{TINJAUAN PUSTAKA}

1. Pelayanan Publik

a. Pengertian Pelayanan Publik

Pelayanan publik adalah perihal kemudahan yang diberikan kepada masyarakat sehubungan dengan barang dan jasa. Berdasarkan Undang-Undang Nomor 25 Tahun 2009 pasal satu 1 ayat 1 yang dimaksud dengan Pelayanan Publik adalah kegiatan atau rangkaian kegiatan dalam rangka pemenuhan kebutuhan pelayanan sesuai dengan peraturan perundang-undangan bagi setiap warga negara dan penduduk atas barang, jasa, dan/atau pelayanan administratif yang disediakan oleh penyelenggara pelayanan publik.

Menurut Kamus Besar Bahasa Indonesia, pelayanan memiliki tiga makna, (1) perihal atau cara melayani, (2) usaha melayani kebutuhan orang lain dengan memperoleh imbalan (uang), serta (3) kemudahan yang diberikan sehubungan dengan jual beli barang atau jasa. Adapun menurut Lovelock (Hardiyansyah, 2018: 10 ), "service adalah produk yang tidak berwujud, berlangsung sebentar dan dirasakan atau dialami." Artinya service merupakan produk yang tidak ada wujud atau bentuknya sehingga tidak ada bentuk yang dapat dimiliki, dan berlangsung sesaat atau tidak tahan lama, tetapi dialami dan dapat dirasakan oleh penerima layanan.Pelayanan umum atau pelayanan publik menurut Sadu Wasistiono(Hardiyansyah, 2018: 11) 
adalah pemberian jasa baik oleh pemerintah, pihak swasta atas nama pemerintah ataupun pihak swasta kepada masyarakat, dengan atau tanpa pembayaran guna memenuhi kebutuhan dan atau kepentingan masyarakat.

b. Asas - Asas Pelayanan Publik

Pelayanan publik dilakukan tiada lain untuk memberikan kepuasan bagi pengguna jasa, karena itu penyelenggaraannya membutuhkan asas-asas pelayanan. Dengan kata lain, dalam memberikan pelayanan publik, instansi penyedia pelayanan publik harus memperhatikan asas pelayanan publik. Asas-asas pelayanan publik menurut pasal 4 Undang-Undang No.25 tahun 2009 sebagai berikut:

1) Kepentingan umum

Layanan publik yang diberikan mengedepankan kepentingan orang banyak. Manfaat yang diperoleh secara prosedural yang digunakan atas nama dan semua masyarakat dalam kaitannya dengan tindakan, keputusan atau kebijakan.

2) Kepastian hukum

Artinya pelayanan publik yang diberikan dari hukum yang oleh ilmu hukum tidak dianggap berasal dari aturan-aturan yang lebih umum. Asas kepastian hukum dipandang sebagai dasar-dasar atau petunjuk-petunjuk bagi hukum yang berlaku.

3) Kesamaan hak

Pelayanan publik yang diberikan kepada warga tanpa terkecuali. Sekalipun ada warga yang tidak taat pajak, tetap akan mendapatkan pelayanan.

4) Keseimbangan hak dan kewajiban

Pelayanan publik harus sebanding antara dana yang dibayarkan dengan layanan yang diberikan.

5) Keprofesionalan

Pelayanan publik bertindak dalam kepentingan publik juga harus memastikan bahwa mereka memiliki kemampuan, dalam hal sumber daya personil yang tepat, kompeten, berpengetahuan, untuk memastikan bahwa tujuan organisasi, proyek, hasil dapat dicapai.

6) Partisipatif

Pelayanan publik mengajak warga yang punya kepentingan untuk ikut terlibat dalam layanan walaupun hanya sekedar menginformasikan layanan, ataupun ikut membayar dan menceburkan diri dalam pelayanan.

7) Persamaan perlakuan / tidak diskriminatif

Pelayanan publik diberikan tanpa memandang dan membeda-bedakan ras, keturunan jabatan ataupun kerabat.

8) Akuntabilitas

Dapat dipertanggungjawabkan sesuai dengan ketentuan peraturan perundangundangan.

9) Fasilitas dan perlakuan khusus bagi kelompok rentan

Penerima layanan publik tidaklah semua ada dalam batas usia yang sama, tapi beragam dengan berbagai macam kondisi kesehatan dan beban kehidupan termasuk jenis kelamin. Mereka dapat saja dibedakan karena kerentanan seperti orang jompo, wanita hamil ataupun dalam kondisi sakit.

10) Ketepatan waktu

Pelayanan publik diberikan dengan prosedur tetap. Didalamnya ada durasi waktupengurusan layanan, sehingga ada kepastian dari sisi waktu pengurusan pelayanan. 
11) Kecepatan, kemudahan, dan keterjangkauan

Pelayanan publik yang diberikan pemerintah diharapkan dapat segera meyelesaikan kebutuhan publik, ada kemudahan dalam akses dan dapat dijangkau oleh masyarakat baik dari sisi biaya maupun lokasi.

c. Jenis Pelayanan Publik

Pelayanan publik dapat dibedakan menjadi :

1) Jenis Pelayanan Administratif,yaitupelayananberupa penyediaan berbagai bentuk dokumen yang dibutuhkan oleh publik, dokumen, misalnya: pembuatan KTP, Sertifikat Tanah, Akta Kelahiran, Akta Kematian,Paspor, dan sebagainya.

2) Jenis Pelayanan Barang, yaitu pelayanan yang menghasilkan berbagai bentuk/jenis barang yang digunakan oleh publik, misalnya: Jaringan telepon, Penyediaan tenaga listrik, Penyediaan air bersih, dan sebagainya.

3) Jenis Pelayanan Jasa, yaitu pelayanan yang menghasilkan berbagai bentuk jasa yang dibutuhkan publik, misalnya: Pendidikan, Pemeliharaan kesehatan, Penyelengaraan transportasi, Jasa pos, dan sebagainya.

d. Kualitas Pelayanan Publik

Kualitas pelayanan diartikan sebagai suatu kondisi dinamis yang berhubungan dengan produk, jasa, manusia, proses dan lingkungan yang memenuhi atau melebihi harapan pelanggan. Kualitas pelayanan berhubungan dengan pemenuhan harapan atau kebutuhan pelanggan.

Menurut Zeithaml et al. (Hardiyansyah, 2018: 63), Kualitas Pelayanan dapat diukur dari 5 dimensi, yaitu: Tangibel (Berwujud), Reliability (Kehandalan), Responsiviness (Ketanggapan), Assurance (Jaminan), dan Empathy (Empati). Masing-masing dimensi memiliki indikator-indikator sebagai berikut:

Untuk Dimensi Tangibel (Berwujud), terdiri atas indikator :

1) Penampilan petugas dalam melayani pelanggan

2) Kenyamanan tempat melakukan pelayanan

3) Kemudahan dalam proses pelayanan

4) Kedisiplinan petugas dalam melakukan pelayanan

5) Kemudahan akses pelanggan dalam permohonan pelayanan

6) Penggunaan alat bantu dalam pelayanan

Untuk Dimensi Reliability (Kehandalan), terdiri atas indikator :

1) Kecermatan petugas dalam melayani pelanggan

2) Memiliki standar pelayanan yang jelas

3) Kemampuan petugas dalam menggunakan alat bantu dalam proses pelayanan

4) Keahlian petugas dalam menggunakan alat bantu dalam proses pelayanan

Untuk Dimensi Responsiviness (Ketanggapan), terdiri atas indikator :

1) Merespon setiap pelanggan yang ingin mendapatkan pelayanan

2) Petugas melakukan pelayanan dengan cepat

3) Petugas melakukan pelayanan dengan tepat

4) Petugas melakukan pelayanan dengan cermat

5) Petugas melakukan pelayanan dengan waktu yang tepat

6) Semua keluhan pelanggan direspon oleh petugas

Untuk Dimensi Assurance (Jaminan), terdiri atas indikator :

1) Petugas memberikan jaminan tepat waktu dalam pelayanan

2) Petugas memberikan jaminan biaya dalam pelayanan 
3) Petugas memberikan jaminan legalitas dalam pelayanan

4) Petugas memberikan jaminan kepastian biaya dalam pelayanan

Untuk Dimensi Empathy (Empati), terdiri atas indikator :

1) Mendahulukan kepentingan pelanggan

2) Petugas melayani dengan sikap yang ramah

3) Petugas melayani dengan sikap sopan santun

4) Petugas melayani dengan tidak diskriminatif

5) Petugas melayani dan menghargai setiap pelanggan

Lima dimensi pelayanan publik tersebut di atas, menurut Zeithaml et al. (Hardiyansyah, 2018: 64) dapat dikembangkan menjadi 10 dimensi sebagai berikut:

1) Tangible, terdiri atas fasilitas fisik, peralatan, personil,dan komunikasi.

2) Reliable, terdiri dari kemampuan unit pelayanan dalam menciptakan pelayanan yang dijanjikan dengan tepat.

3) Responsiveness, kemauan untuk membantu konsumen bertanggungjawab terhadap mutu layanan yang diberikan.

4) Competence, tuntutan yang dimilikinya, pengetahuan dan keterampilan yang baik oleh petugas dalam memberikan layanan.

5) Courtesy, sikap atau perilaku ramah, bersahabat, tanggap terhadap keinginan konsumen serta mau melakukan kontak atau hubungan pribadi.

6) Credibility, sikap jujur dalam setiap upaya untuk menarik kepercayaan masyarakat.

7) Security, jasa pelayanan yang diberikan harus dijamin bebas dari berbagai bahaya dan resiko.

8) Acces, terdapat kemudahan untuk mengadakan kontak dan pendekatan.

9) Communication, kemauan pemberi layanan untuk mendengarkan suara, keinginan atau aspirasi pelanggan, sekaligus kesediaan untuk selalu menyampaikan informasi baru kepada masyarakat.

10) Understanding the customer, melakukan segala usaha untuk mengetahui kebutuhan pelanggan.

2. Kepuasan Masyarakat

a. Pengertian Kepuasan Masyarakat

Menurut Nasution M. N. (Suandi, 2019:16), kepuasan pelanggan (masyarakat) adalah suatu keadaan di mana kebutuhan, keinginan, dan harapan pelanggan dapat terpenuhi melalui produk yang dikonsumsi. Gerson(Suandi,2019:16) menyatakan bahwa kepuasan pelanggan merupakan harapan yang telah terpenuhi atau terlampaui. Dari pendapat para pakar tersebut dapat disimpulkan kepuasan pelanggan adalah tingkat perasaan konsumen setelah membandingkan kesesuaian atau ketidaksesuaian antara harapan (expectation) pelanggan dengan persepsi/pelayanan yang diterima (kenyataan yang dialami).

b. Tingkat Kepuasan Masyarakat

Kepuasan masyarakat terhadap organisasi publik sangat penting karena berhubungan dengan kepercayaan masyarakat. Harbani Pasolong (Suandi,2019:1617), menyatakan bahwa semakin baik kepemerintahandan kualitas pelayanan yang diberikan, maka akan semakin tinggi kepercayaan masyarakat (high trust). Kepercayaan masyarakatakan semakin tinggi apabila masyarakat mendapatkan pelayananyang baik dan merasa terpuaskan akan pelayanan tersebut. 
Setiap penyelenggara pelayanan perlu mengukur kepuasan pelanggan guna melihat umpan balik maupun masukan yang dapat diambil oleh penyelenggara untuk keperluan pengembangan dan implementasi strategi peningkatan kepuasan pelanggan. Menurut KEPMENPAN Nomor 63 tahun 2003 tentang Pedoman Umum Penyelenggaraan

Pelayanan Publik, ukuran keberhasilan penyelenggaraan pelayanan ditentukan oleh tingkat kepuasan penerima pelayanan. Kepuasan pelayanan dicapai apabila penerima pelayanan memperoleh pelayanan sesuai dengan yang dibutuhkan dan diharapkan. Oleh sebab itu, setiap penyelenggara pelayanan secara berkala melakukan survei Indeks Kepuasan Masyarakat. Kepuasan pelanggan dapat diukur menggunakan berbagai metode pengukuran. Kotler (Suandi,2019:17), secara sederhana mengemukakan empat metode yang dapat mengukur kepuasan pelanggan, yaitu sebagaiberikut:

1) Sistem Keluhan dan Saran

Setiap perusahaan yang berorientasi kepada pelanggan (customer-oriented) perlu memberikan kesempatan seluasluasnya bagi para pelanggannya untuk menyampaikan saran, pendapat, dan keluhan. Media yang bisa digunakan adalah kotak saran, kartu komentar, saluran telepon khusus (customer hot lines), dan lainlain.

2) Survei Kepuasan Pelanggan

Melalui survai, perusahaan akan memperoleh tanggapan dan umpan balik secara langsung dari pelanggan dan sekaligus juga memberikan tanda (signal) positif bahwa perusahaan menaruh perhatian terhadap pelanggannya.

3) Ghost Shopping

Metode ini dilakukan dengan cara mempekerjakan beberapa orang (ghost shopper) untuk berperan atau bersikap sebagai pelanggan potensial produk perusahaan dan pesaing. Lalu ghost shopper tersebut menyampaikan temuantemuannya mengenai kekuatan dan kelemahan produk perusahaan dan pesaing berdasarkan pengalaman mereka.

4) Lost Customer Analysis

Perusahaan yang menggunakan metode ini untuk menganalisis kepuasan pelanggan dengan cara menghubungi para pelanggannya yang telah berhenti membeli atau telah beralih pemasok. Hasil dari metode ini akan diperoleh informasi penyebab terjadinya hal tersebut. Informasi ini sangat berguna bagi perusahaan untuk mengambil langkah kebijakan selanjutnya dalam rangka meningkatkan kepuasan dan loyalitas pelanggan. Berdasarkan penjabaran tersebut, terdapat empat metode yang dapat dilakukan untuk mengukur kepuasan pelanggan, yaitu dengan metode sistem keluhan atau saran, survei kepuasan pelanggan, metode ghost shopping, dan lost customer analysis.

c. Indikator Kepuasan Masyarakat

Menurut Peraturan Menteri PAN-RB No.14 Tahun 2017 Tentang Pedoman Penyusunan Survei Kepuasan Masyarakat, terdapat Sembilan (9) indikator kepuasan masyarakat diantaranya, yaitu sebagai berikut:

1). Persyaratan

Persyaratan adalah syarat yang harus dipenuhi dalam pengurusan suatu jenis pelayanan, baik persyaratan teknis maupun administratif.

2). Sistem, Mekanisme, dan Prosedur

Prosedur adalah tata cara pelayanan yang dibakukan bagi pemberi dan penerima pelayanan, termasuk pengaduan. 
3). Waktu Penyelesaian

Waktu penyelesaian adalah jangka waktu yang diperlukan untuk menyelesaikan seluruh proses pelayanan dari setiap jenis pelayanan.

4). Biaya/Tarif

Biaya/Tarif adalah ongkos yang dikenakan kepada penerima layanan dalam mengurus dan/atau memperoleh pelayanan dari penyelenggara yang besarnya ditetapkan berdasarkan kesepakatan antara penyelenggara dan masyarakat.

5). Produk Spesifikasi Jenis Pelayanan

Produk spesifikasi jenis pelayanan adalah hasil pelayanan yang diberikan dan diterima sesuai dengan ketentuan yang telah ditetapkan. Produk pelayanan ini merupakan hasil dari setiap spesifikasi jenis pelayanan.

6). Kompetensi Pelaksana

Kompetensi pelaksana adalah kemampuan yang harus dimiliki oleh pelaksana meliputi pengetahuan, keahlian, keterampilan, dan pengalaman.

7). Perilaku Pelaksana pelayanan.

Perilaku pelaksana adalah sikap petugas dalam memberikan

8). Penanganan Pengaduan, Saran dan Masukan

Penanganan pengaduan, saran dan masukan, adalah tata cara pelaksanaan penanganan pengaduan dan tindak lanjut.

9). Sarana dan prasarana

Sarana adalah segala sesuatu yang dapat dipakai sebagai alat dalam mencapai maksud dan tujuan. Prasarana adalah segala sesuatu yang merupakan penunjang utama terselenggaranya suatu proses (usaha, pembangunan, proyek). Sarana digunakan untuk benda yang bergerak (komputer, mesin) dan prasarana untuk benda yang tidak bergerak (gedung).

\section{Hipotesa}

Hipotesa dalam penelitian ini adalah Diduga terdapat pengaruh yang signifikan antara variabel X (Kualitas Pelayanan Publik) terhadap variabel Y (Kepuasan Masyarakat).

\section{METODE PENELITIAN}

\section{A. Jenis Penelitian}

Dalam penelitian ini menggunakan metode kuantitatif. Menurut Sugiyono (2016: 8) metode penelitian kuantitatif dapat diartikan sebagai metode penelitian yang berlandaskan filsafat positif digunakan untuk meneliti pada populasi atau sampel tertentu. Metode kuantitatif jenis metode yang menekankan pada analisis data-data yang berhubungan dengan numerik atau angka yang dikelola dengan metode statistika yang nantinya akan menjadi suatu data output yang telah matang atau siap untuk digunakan. Metode ini sebagai metode ilmiah atau scientific karena telah memenuhi kaidah-kaidah ilmiah yaitu konkrit atau empiris, objektif, terukur, rasional, dan sistematis.

\section{B. Populasi dan Sampel}

\section{Populasi}

Populasi dalam penelitian ini adalah seluruh masyarakat yang berkunjung di Dinas Tenaga Kerja dan Transmigrasi Kabupaten Bantul selama dilakukan penelitian yang berjumlah 50 orang. 
2. Sampel

Pengambilan sampel dalam populasi ini menggunakan teknik non-probability sampling dengan jenis accidental sampling, yaitu teknik penentuan sampel berdasarkan faktor spontanitas, artinya siapa saja yang secara tidak sengaja bertemu dengan peneliti dan sesuai dengan karakteristik atau ciri-cirinya yaitu masyarakat yang menjadi pelanggan di Dinas Tenaga Kerja dan Transmigrasi Kabupaten Bantul, maka orang tersebut dapat digunakan sebagai sampel.

Dalam penelitian ini menggunakan metode Slovin untuk mengetahui jumlah sampel yang dibutuhkan. Cara menentukan ukuran sampel dengan metode Slovin, sebagai berikut:

Dimana:

$$
\mathrm{n}=\frac{\mathrm{N}}{1+\mathrm{N} \cdot e^{2}}
$$

$\mathrm{n}=$ Besarnya sampel

$\mathrm{N}=$ Populasi

$\mathrm{E}=$ Error (Persentase kesalahan yang dapat ditolerir dalam mengambil sampel) dan tingkat error yang penulis tetapkan adalah 5\%

Berdasarkan rumus diatas, maka dapat ditentukan besarnya sampel sebagai berikut:

$$
\begin{aligned}
& \mathrm{n}=\frac{50}{1+50(0,05)^{2}} \\
& \mathrm{n}=\frac{50}{1,125} \\
& \mathrm{n}=44,4444444444 \\
& \mathrm{n}=44 \text { (dibulatkan jadi } 44 \text { responden) }
\end{aligned}
$$

Berdasarkan perhitungan diatas, jumlah sampel dalam penulisan ini yaitu sebanyak 44 responden.

C. Sumber Data

1. Data Primer

Pengumpulan data primer dalam penelitian ini melalui cara menyebarkan kuesioner dan melakukan wawancara secara langsung dengan masyarakat yang berkunjung di Dinas Tenaga Kerja dan Transmigrasi Kabupaten Bantul.

2. Data Sekunder

Data sekunder yang diperoleh yaitu informasi mengenai visi, misi, tugas pokok, fungsi dan struktur organisasi, serta informasi lainnya yang tercatat berupa catatan, agenda maupun landasan hukum. Pengumpulan data sekunder ini digunakan untuk memperkuat penemuan dan melengkapi informasi yang telah dikumpulkan.

D. Teknik Pengumpulan Data

Menurut Sugiyono (2016:137) terdapat dua hal utama yang mempengaruhi kualitas data hasil penulisan, yaitu kualitas instrumen penulisan., dan kualitas pengumpulan data. Kualitas Instrumen penulisan berkenaan dengan validitas dan realibilitas instrumen dan kualitas pengumpulan data berkenaan dengan ketepatan cara-cara yang digunakan untuk pengumpulkan data. Teknik pengumpulan data yang digunakan dalam penulisan ini diantaranya adalah:

1. Kuesioner (Angket)

Menurut Sugiyono (2016:142) kuesioner (angket) merupakan teknik pengumpulan data yang dilakukan dengan cara memberi seperangkat pertanyaan atau pernyataan tertulis kepada responden untuk dijawabnya. Penyebaran kuesioner dilakukan pada tanggal 15 
Februari 2021 sebanyak 45 kuesioner. Kuesioner dalam LTA ini menggunakan alat ukur Skala Likertdengan 4 skala pengukuran atau dengan 4 alternatif jawaban, yaitu SS = Sangat Setuju, $\mathrm{S}=$ Setuju, TS = Tidak Setuju, STS = Sangat Tidak Setuju.

2. Teknik Pengamatan / Observasi

Menurut Hadi (Sugiyono, 2016:145) mengemukakan bahwa, observasi merupakan suatu proses yang kompleks, suatu proses yang tersusun dari berbagai proses biologis dan psikologis. Dua di antara yang terpenting adalah proses-proses pengamatan dan ingatan. Penulis melakukan observasi dengan mengamati dan mencari tahu tentang tingkat kepuasan masyarakat terhadap pelayanan publik yang mereka terima.

3. Studi Pustaka

Studi pustaka merupakan metode yang digunakan dalam pengumpulan data dengan cara mengumpulkan bahan-bahan dari berbagai sumber dan mempelajari literatur-litaratur untuk memperoleh teori-teori yang berhubungan dengan topik pembahasan. Studi pustaka yang dilakukan yaitu mengumpulkan dari berbagai sumber berupa buku, laporan terdahulu, panduan dan lain sebagainya.

E. Metode Analisis Data

Menurut Sugiyono (2016:147) analisis data merupakan kegiatan setelah data dari seluruh responden atau sumber data lain terkumpul. Untuk penulisan yang tidak merumuskan hipotesis, langkah terakhir tidak dilakukan. Metode analisis data dapat dilakukan sebagai berikut:

1. Analisis Statistik Deskriptif

Menurut Sugiyono (2016:147) statistik digunakan untuk menganalis data dengan cara mendeskripsikan atau menggambarkan data yang telah terkumpul sebagaimana adanya tanpa maksud membuat kesimpulan yang berlaku untuk umum atau generelasi. Dalam penulisan ini, analisa data deskriptif yang digunakan merupakan karateristik responden.

2. Uji Instrumen

Menurut Sugiyono (2016:222) dalam penulisan kuantitatif, kualitas instrumen penulisan berkenaan dengan validitas dan reliabilitas instrumen dan kualitas pengumpulan data berkenaan ketepatan cara-cara yang digunakan untuk mengumpulkan data. Instrumen dalam penulisan kuantitif dapat berupa tes, pedoman wawancara, pedoman observasi dan kuesioner. Instrumen yang digunakan untuk mengukur tingkat tercapainya tujuan maka instrumen harus disusun berdasarkan tujuan yang telah dirumuskan, yaitu:

a. Uji Validitas

Menurut Ghozali (2013:52) uji validitas digunakan untuk mengukur sah atau tidaknya suatu kuesioner. Suatu kuesioner dikatakan valid jika pertanyaan pada kuesioner mampu mengungkapkan sesuatu yang akan diukur oleh kuesioner tersebut. Pengujian validitas dapat dilakukan dengan melihat korelasi antara skor masingmasing item dengan total skor yang ingin diukur. Pengujian validitas dilakukan dengan membandingkan nilai $r$ hitung dengan nilai $r$ tabel, dengan alpha sebesar $5 \%$, jika $r$ hitung $>r$ tabel maka data dinyatakan valid, sedangkan jika $r$ hitung $<\mathrm{r}$ tabel maka data dinyatakan tidak valid.

b. Uji Reliabilitas

Menurut Ghozali (2013:47) Uji reliabilitas merupakan alat untuk mengukur suatu kuesioner yang merupakan indikator dari variable atau konstruk. Suatu kuesioner dikatakan reliable atau handal jika jawaban seseorang terhadap pernyataan adalah konsisten atau stabil dari waktu kewaktu. Pengujian reliabilitas dapat dilakukan dengan menggunakan Cronbach Alpha. Jika nilai alpha hitung > 0,60 maka kontruk 
pertanyaan/pernyataan adalah reliable, sedangkan jika alpha hitung $<0,60$ maka kontruk pertanyaan/pernyataan tidak reliable.

c. Uji Normalitas

Menurut Ghozali (2013:160) Uji normalitas bertujuan untuk mengetahui apakah masing-masing variabel berdistribusi normal atau tidak. Dalam penulisan ini pengujian normalitas menggunakan uji Kolmogorov Smirnov, residual berdistribusi normal jika memiliki nilai signifikansi lebih dari 0,05 .

\section{Analisis Regresi Linier Sederhana}

Menurut Suyono (2018:5) model regresi linier sederhana adalah model probabilistik yang menyatakan hubungan linier antara dua variabel di mana salah satu variabel dianggap mempengaruhi variabel yang lain. Variabel yang mempengaruhi dinamakan variabel independen dan variabel yang dipengaruhi dinamakan variabel dependen. Variabel independen dalam penulisan ini adalah kualitas pelayanan dan variabel dependennya adalah kepuasan masyarakat.

4. Uji t

Menurut Ghozali (2013:98) Uji t pada dasarnya menunjukkan seberapa jauh pengaruh satu variabel independen secara individual dalam menerangkan variabel dependen. Uji t mempunyai nilai signifikan 0,05 Jika sig $<0,05$ maka Ho ditolak Ha diterima, jika angka sig $>0,05$ maka Ho diterima Ha ditolak.

5. Uji Koefisien Determinasi $\mathrm{R}^{2} \mathrm{Uji}$

Uji Koefisien Determinasi $\mathrm{R}^{2}$ bertujuan untuk mengetahui jumlah atau model persentase sumbangan pengaruh variabel $X$ dalam model regresi yang secara serentak atau bersama-sama memberikan pengaruh terhadap variabel $\mathrm{Y}$.

\section{Pembahasan}

1. Karakteristik Responden

a. Responden Berdasarkan Jenis Kelamin

Karakteristik responden berdasarkan jenis kelamin dapat dilihat pada tabel di bawah ini.

Tabel 4.1

Responden Berdasarkan Jenis Kelamin

\begin{tabular}{|ll|l|l|l|l|}
\hline & & & & $\begin{array}{l}\text { Cumulative } \\
\text { Percent }\end{array}$ \\
\hline Valid & Laki-Laki & 13 & 29.5 & 29.5 & 29.5 \\
& Perempuan & 31 & 70.5 & 70.5 & 100.0 \\
Total & 44 & 100.0 & 100.0 & \\
\hline
\end{tabular}

Sumber: data primer diolah. 2021

Berdasarkan tabel di atas dapat diketahui bahwa jumlah responden laki-laki dalam penulisan ini sebanyak 13 responden dengan proporsi 29,5\%. Sedangkan jumlah responden perempuan sebanyak 31 responden dengan proporsi 70,5\%. Lebih jelasnya dapat dilihat pada gambar berikut 


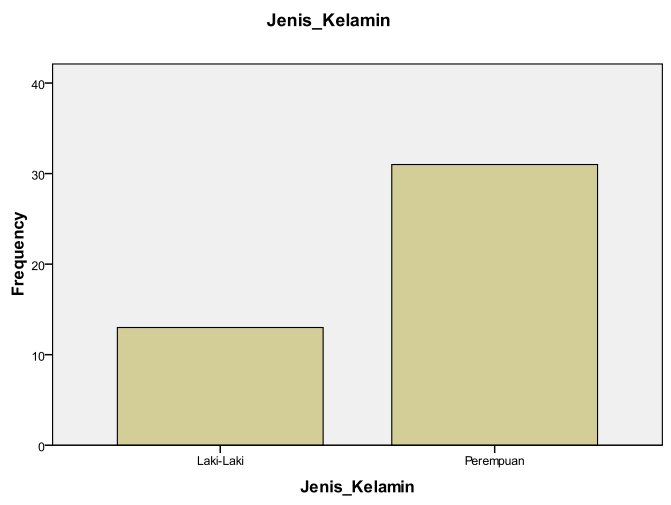

Gambar 4.1

Karakteristik Responden Berdasarkan Jenis Kelamin

b. Responden Berdasarkan Umur

Karakteristik responden berdasarkan umur dapat dilihat pada tabel di bawah ini.

Tabel 4.2

Responden Berdasarkan Umur

\begin{tabular}{|ll|l|l|l|l|}
\hline & & Frequency & Percent & Valid Percent & Cumulative Percent \\
\hline Valid & $17-20$ & 19 & 43.2 & 43.2 & 43.2 \\
& $21-25$ & 13 & 29.5 & 29.5 & 72.7 \\
$26-30$ & 6 & 13.6 & 13.6 & 86.4 \\
$31-35$ & 3 & 6.8 & 6.8 & 93.2 \\
$36-40$ & 2 & 4.5 & 4.5 & 97.7 \\
$41-45$ & 1 & 2.3 & 2.3 & 100.0 \\
Total & 44 & 100.0 & 100.0 & \\
\hline
\end{tabular}

Sumber: data primer diolah. 2021

Berdasarkan tabel di atas dapat diketahui bahwa frekuensi karakteristik responden berdasarkan umur terendah terdapat pada interval umur 41- 45 tahun sebanyak 1 orang dengan proporsi $2,3 \%$. Sedangkan frekuensi tertinggi terdapat pada interval umur 17-20 tahun sebanyak 19 orang dengan proporsi $43,2 \%$. Lebih jelasnya dapat dilihat pada gambar berikut :

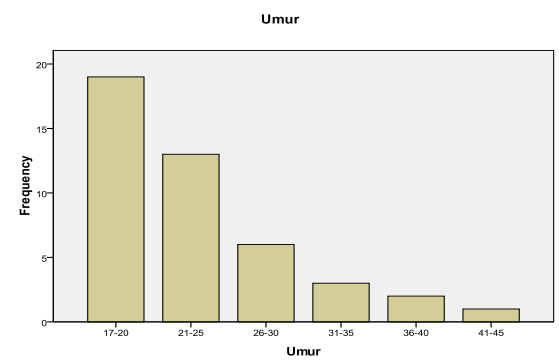

Gambar 4.2

Karakteristik Responden Berdasarkan Umur 
c. Responden Berdasarkan Pendidikan

Karakteristik responden berdasarkan umur dapat dilihat pada tabel di bawah ini.

Tabel 4.3

Responden Berdasarkan Pendidikan

Pendidikan

\begin{tabular}{|ll|l|l|l|l|}
\hline & & Frequency & Percent & Valid Percent & Cumulative Percent \\
\hline Valid & SMP & 4 & 9.1 & 9.1 & 9.1 \\
& SMA & 30 & 68.2 & 68.2 & 77.3 \\
& S1 & 10 & 22.7 & 22.7 & 100.0 \\
& Total & 44 & 100.0 & 100.0 & \\
\hline
\end{tabular}

Sumber: data primer diolah. 2021

Berdasarkan tabel di atas dapat diketahui bahwa frekuensi karakteristik responden berdasarkan pendidikan terendah terdapat pada jenis pendidikan SMP sebanyak 4 orang dengan proporsi $9,1 \%$. Sedangkan frekuensi tertinggi terdapat pada jenis pendidikan SMA sebanyak 30 orang dengan proporsi $68,2 \%$. Lebih jelasnya dapat dilihat pada gambar berikut :

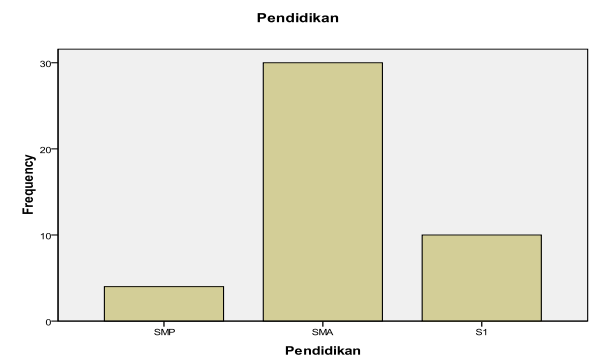

Gambar 4.3

Karakteristik Responden Berdasarkan Pendidikan

2. Uji Instrumen

a. Uji Validitas

Pengujian validitas dilakukan dengan membandingkan nilai $\mathrm{r}$ hitung dengan nilai $r$ tabel, dengan alpha sebesar 5\%, jika $r$ hitung $>r$ tabel maka data dinyatakan valid, sedangkan jika $r$ hitung $<\mathrm{r}$ tabel maka data dinyatakan tidak valid.

Tabel 4.4

Uji Validitas Variabel Kualitas Pelayanan Publik (X)

\begin{tabular}{|l|l|l|l|}
\hline Item & r hitung & \multirow{2}{*}{$\mathrm{r}$ tabel } & Keterangan \\
\hline P1 & 0,798 & \multirow{5}{*}{} & Valid \\
\hline P2 & 0,686 & & Valid \\
\hline P3 & 0,713 & Valid \\
\hline P4 & 0,486 & \multirow{5}{*}{0,2973} & Valid \\
\hline P5 & 0,817 & Valid \\
\hline P6 & 0,837 & Valid \\
\hline P7 & 0,771 & & Valid \\
\hline P8 & 0,753 & & Valid \\
\hline Pn & 0,779 & & Valid \\
\hline
\end{tabular}

Sumber: data primer diolah 2021 
Dari tabel diatas dapat diketahui bahwa instrumen variabel Pelayanan Publik (X) dinyatakan semuanya valid, karena nilai $\mathrm{r}$ hitung lebih besar dari nilai $\mathrm{r}$ tabel $=$ 0,2973

Tabel 4.5

Uji Validitas Variabel Kepuasan Masyarakat (Y)

\begin{tabular}{|l|l|l|l|}
\hline Item & r hitung & r tabel & Keterangan \\
\hline P1 & 0,631 & \multirow{5}{*}{} & Valid \\
\hline P2 & 0,610 & Valid \\
\hline P3 & 0,722 & & Valid \\
\hline P4 & 0,511 & \multirow{5}{*}{0,2973} & Valid \\
\hline P5 & 0,666 & Valid \\
\hline P6 & 0,795 & Valid \\
\hline P7 & 0,718 & & Valid \\
\hline P8 & 0,742 & & Valid \\
\hline P9 & 0,687 & & Valid \\
\hline
\end{tabular}

Sumber: data primer diolah. 2021

Dari tabel diatas dapat diketahui bahwa instrumen variabel Pelayanan Publik (Y) dinyatakan semuanya valid, karena nilai $r$ hitung lebih besar dari nilai $r$ tabel $=$ 0,2973

b. Uji Reliabilitas

Uji reliabilitas dapat dilakukan dengan membandingkan nilai alpha hitung dengan nilai standar $=0,60$. Jika nilai alpha hitung $>0,60$ maka kontruk pertanyaan adalah reliable, sedangkan jika alpha hitung $<0,60$ maka kontruk pertanyaan tidak reliable.

Tabel 4.6

Uji Reliabilitas Variabel X dan Variabel Y

\begin{tabular}{|l|l|l|l|}
\hline No & Variabel & Apha $(\alpha)$ & Keterangan \\
\hline 1 & Kualitas Pelayanan Publik $(\mathrm{X})$ & 0,874 & Reliabel \\
\hline 2 & Kepuasan Masyarakat (Y) & 0,850 & Reliabel \\
\hline
\end{tabular}

Sumber: data primer diolah. 2021

Berdasarkan hasil uji reliabilias tersebut, dapat disimpulkan bahwa seluruh variabel yang digunakan dalam penulisan ini adalah reliabel, hal tersebut dikarenakan koefisien Cronbach's Alpha di atas 0,6.

c. Uji Normalitas

Pengujian normalitas menggunakan uji Kolmogorov Smirnov, dalam hal ini untuk mengetahui apakah suatu data terdistribusi secara normal adalah jika nilai signifikan lebih dari 0,05 . 
Tabel 4.7

Uji Normalitas

One-Sample Kolmogorov-Smirnov Test

\begin{tabular}{|ll|l|}
\hline & & $\begin{array}{l}\text { Unstandardized } \\
\text { Residual }\end{array}$ \\
\hline $\mathrm{N}$ & & 44 \\
Normal Parameters ${ }^{\mathrm{a}, \mathrm{b}}$ & Mean & .0000000 \\
& Std. Deviation & .93023054 \\
Most Extreme Differences & Absolute & .125 \\
& Positive & .087 \\
& Negative & -.125 \\
Kolmogorov-Smirnov Z & & .828 \\
Asymp. Sig. (2-tailed) & & .499 \\
\hline
\end{tabular}

a. Test distribution is Normal.

b. Calculated from data.

Sumber: data primer diolah. 2021

Berdasarkan hasil uji normalitas tersebut, diperoleh Asymp. Sig. sebesar 0,499. Nilai sig $>0,05$ maka dapat disimpulkan bahwa data berdistribusi normal.

d. Uji Regresi Linear Sederhana

Uji regresi linier sederhana dilakukan untuk mengetahui hubungan atau pengaruh variabel $\mathrm{x}$ terhadap variabel $\mathrm{y}$. Berikut hasil tabel output coefficiens regresi sederhana kualitas pelayanan publik dan kepuasan masyarakat.

Tabel 4.8

Uji Regresi Linear Sederhana

\section{Coefficients $^{\mathrm{a}}$}

\begin{tabular}{|c|c|c|c|c|c|c|}
\hline \multirow{2}{*}{\multicolumn{2}{|c|}{ Model }} & \multicolumn{2}{|c|}{ Unstandardized Coefficients } & \multirow{2}{*}{\begin{tabular}{|l|}
$\begin{array}{l}\text { Standardized } \\
\text { Coefficients }\end{array}$ \\
Beta \\
\end{tabular}} & \multirow[b]{2}{*}{$\mathrm{t}$} & \multirow[b]{2}{*}{ Sig. } \\
\hline & & B & Std. Error & & & \\
\hline \multirow[t]{2}{*}{1} & (Constant) & 7.659 & 1.082 & & 7.079 & .000 \\
\hline & $\begin{array}{l}\text { Kualitas Pelayanan } \\
\text { Publik }\end{array}$ & .781 & .034 & .962 & 22.884 & .000 \\
\hline
\end{tabular}

a. Dependent Variable: Kepuasan Masyarakat

Sumber: data primer diolah. 2021

Dari hasil perhitungan didapatkan konstanta (a) sebesar 7,659. Sedangkan nilai Kualitas Pelayanan Publik atau koefisien regresi (b) sebesar 0,781, sehingga persamaan regresinya dapat ditulis:

$\mathrm{Y}=\mathrm{a}+\mathrm{bx}$

$\mathrm{Y}=7,659+0,781 \mathrm{x}$

Dari persamaan regresi linier sederhana diatas, dapat dijelaskan bahwa:

1) Nilai konstanta sebesar 7,659 artinya apabila variabel pengaruh kualitas pelayanan nilainya 0 (tidak ada), maka kepuasan masyarakat positif sebesar 7,659 .

2) Koefisien regresi variabel pengaruh kualitas pelayanan publik 0,781 artinya jika pengaruh kualitas pelayanan publik mengalami kenaikan satu satuan, maka kepuasan masyarakat mengalami peningkatan sebesar 0,781 satuan maka koefisien bersifat positif. 
e. Uji t

Uji $t$ pada dasarnya menunjukkan seberapa jauh pengaruh variabel independen dalam variabel dependen.

Tabel 4.9

Uji t

\section{Coefficients $^{\mathrm{a}}$}

\begin{tabular}{|c|c|c|c|c|c|c|}
\hline \multirow[b]{2}{*}{ Model } & & \multicolumn{2}{|c|}{ Unstandardized Coefficients } & \multirow{2}{*}{\begin{tabular}{|l|}
$\begin{array}{l}\text { Standardized } \\
\text { Coefficients }\end{array}$ \\
Beta \\
\end{tabular}} & \multirow[b]{2}{*}{$\mathrm{t}$} & \multirow[b]{2}{*}{ Sig. } \\
\hline & & B & Std. Error & & & \\
\hline 1 & (Constant) & 7.659 & 1.082 & & 7.079 & .000 \\
\hline & $\begin{array}{l}\text { Kualitas } \\
\text { Pelayanan } \\
\text { Publik }\end{array}$ & .781 & .034 & .962 & 22.884 & .000 \\
\hline
\end{tabular}

a. Dependent Variable: Kepuasan Masyarakat

Sumber: data primer diolah. 2021

Ha : Diduga terdapat pengaruh yang signifikan antara variabel $\mathrm{X}$ (Kualitas Pelayanan Publik) dengan Variabel Y (Kepuasan Masyarakat).

Ho : Diduga tidak terdapat pengaruh yang signifikan antara variabel $\mathrm{X}$ (Kualitas Pelayanan Publik) dengan Variabel Y (Kepuasan Masyarakat).

1) Menentukan nilai Ho dan Ha

Uji t dilakukan dengan menggunakan ketentuan, jika sig $<0,05$ maka Ho ditolak Ha diterima, jika angka sig $>0,05$ maka Hoditerima Ha ditolak. Berdasarkan tabel di atas nilai signifikansinya adalah 0,000 dimana 0,000< 0.05 sehingga Ho ditolak dan $\mathrm{Ha}$ diterima. Dengan demikian terdapat pengaruh yang signifikan antara variabel $\mathrm{X}$ (Kualitas Pelayanan Publik) dengan Variabel Y (Kepuasan Masyarakat) di Dinas Tenaga Kerja dan Transmigrasi Kabupaten Bantul DIY.

2) Menentukan nilai tabel

Perhitungan $\mathrm{t}$ hitung $>\mathrm{t}$ tabel maka Ha diterima atau variabel terikat terbukti bahwa mempengaruhi variabel bebas atau Ho. Berikut perhitungan $t$ tabel:

$\mathrm{df}=\mathrm{n}-\mathrm{k}-1$

Keterangan:

$\mathrm{df}=$ degree of freedom

$\mathrm{n}=$ responden

$\mathrm{k}=$ variabel

$\mathrm{df}=\mathrm{n}-\mathrm{k}-1$

$=44-1-1=42$

Jadi hasil dari perhitungan di atas df adalah 42, maka t tabelnya adalah 2,01808 .

Dari hasil tabel di atas t hitung adalah 22,884 dan t tabelnya adalah 2,01808 maka 22,884 $>2,01808$ sehingga Ho ditolak dan Ha diterima. Sehingga terdapat pengaruh yang signifikan antara variabel X (Kualitas Pelayanan Publik) dengan Variabel Y (Kepuasan Masyarakat) di Dinas Tenaga Kerja dan Transmigrasi Kabupaten Bantul DIY.

f. Uji Koefisien Determinasi R Square

Nilai koefisien R square ini berguna untuk melihat seberapa besar kontribusi pengaruh yang diberikan variabel kualitas pelayanan publik (X) secara simultan (bersama-sama) terhadap variabel kepuasan masyarakat (Y). 
Tabel 4.10

Uji Koefisien Determinasi R Square

Model Summary ${ }^{b}$

\begin{tabular}{|c|c|c|c|c|}
\hline Model & $\mathrm{R}$ & R Square & $\begin{array}{|ll|}\begin{array}{l}\text { Adjusted } \\
\text { Square }\end{array} & \mathrm{R} \\
\end{array}$ & Std. Error of the Estimate \\
\hline 1 & $.962^{\mathrm{a}}$ & .926 & .924 & .941 \\
\hline
\end{tabular}

a. Predictors: (Constant), X

b. Dependent Variable: Y

Sumber: data primer diolah. 2021

Berdasarkan tabel di atas diketahui bahwa variabel kualitas pelayanan publik (X) memiliki kemampuan dalam memberikan kontribusi pada variabel kepuasan masyarakat (Y) sebesar 0,926 (92,6\%). Sedangkan variabel-variabel lain diluar penulisan memiliki kemampuan memberikan kontribusi terhadap variabel kepuasan masyarakat (Y) sebesar 7,4\%.

\section{Kesimpulan}

Berdasarkan hasil dari perhitungan di atas dapat disimpulkan bahwa:

1. Terdapat pengaruh yang signifikan antara variabel $X$ (Kualitas Pelayanan Publik) dengan variabel Y (Kepuasan Masyarakat) di Dinas Tenaga Kerja dan Transmigrasi Kabupaten Bantul DIY.

2. Variabel X (Kualitas Pelayanan Publik) memiliki kemampuan dalam memberikan kontribusi pada variabel Y (Kepuasan Masyarakat) sebesar 92,6\%. Sedangkan variabel-variabel lain diluar penulisan memiliki kemampuan memberikan kontribusi terhadap variabel Y (Kepuasan Masyarakat) sebesar 7,4\%.

\section{Saran}

Diharapkan adanya kerjasama antara masyarakat dengan Dinas Tenaga Kerja dan Transmigrasi Kabupaten Bantul untuk mensosialisasikan informasi-informasi mengenai produk pelayanan, prosedur dan persyaratan yang harus dipenuhi.

\section{DAFTAR PUSTAKA}

Ghozali, Imam, 2013, Aplikasi Analisis Multivariate dengan Program SPSS, Semarang: Universitas Diponegoro.

Hardiyansyah, 2018 , Kualitas Pelayanan Publik, Yogyakarta : Gava Media.

Irawan, Handi, 2012, 10 Prinsip Kepuasan Pelanggan, Jakarta: PT. Gramedia.

Rahmadana, Muhammad Fitri,dkk, 2020, Pelayanan Publik, Medan: Yayasan Kita Menulis.

Suandi, 2019, Analisis Kepuasan Masyarakat Terhadap Pelayanan Publik Berdasarkan Indeks Kepuasan Masyarakat di Kantor Kecamatan Belitang Kabupaten OKU Timur, Jurnal Ilmu Administrasi dan Studi Kebijakan (JIASK), 1(2), 13-22.

Sugiyono, 2016, Metode Penulisan Kuantitatif, Kualitatif dan R\&D, Alfabeta, Bandung: CV Alfabeta. 
Suyono, 2018, Analisis Regresi Untuk Penelitian, Yogyakarta: Deepublish.

Teguh Widodo, 2017, Manajemen Publik (Public Manajemen), Yogyakarta: Deepublish. 